\title{
High levels of gene flow and genetic diversity in Irish populations of Salix caprea L. inferred from chloroplast and nuclear SSR markers
}

\author{
Aude C Perdereau ${ }^{1,2,3^{*}}$, Colin T Kelleher ${ }^{4}$, Gerry C Douglas ${ }^{1}$ and Trevor R Hodkinson ${ }^{2,3}$
}

\begin{abstract}
Background: Salix caprea is a cold-tolerant pioneer species that is ecologically important in Europe and western and central Asia. However, little data is available on its population genetic structure and molecular ecology. We describe the levels of geographic population genetic structure in natural Irish populations of $\mathrm{S}$. caprea and determine the extent of gene flow and sexual reproduction using both chloroplast and nuclear simple sequence repeats (SSRS).

Results: A total of 183 individuals from 21 semi-natural woodlands were collected and genotyped. Gene diversity across populations was high for the chloroplast SSRs $\left(H_{T}=0.21-0.58\right)$ and 79 different haplotypes were discovered, among them $48 \%$ were unique to a single individual. Genetic differentiation of populations was found to be between moderate and high (mean $G_{S T}=0.38$ ). For the nuclear SSRS, $G_{S T}$ was low at 0.07 and observed heterozygosity across populations was high $\left(H_{O}=0.32-0.51\right)$; only $9.8 \%$ of the genotypes discovered were present in two or more individuals. For both types of markers, AMOVA showed that most of the variation was within populations. Minor geographic pattern was confirmed by a Bayesian clustering analysis. Gene flow via pollen was found to be approximately 7 times more important than via seeds.
\end{abstract}

Conclusions: The data are consistent with outbreeding and indicate that there are no significant barriers for gene flow within Ireland over large geographic distances. Both pollen-mediated and seed-mediated gene flow were found to be high, with some of the populations being more than $200 \mathrm{~km}$ apart from each other. These findings could simply be due to human intervention through seed trade or accidental transportation of both seeds and pollen. These results are of value to breeders wishing to exploit natural genetic variation and foresters having to choose planting material.

Keywords: Genetic diversity, Microsatellites, Population structure, Salix, Willow

\section{Background}

The genus Salix L. (willows, sallows and osiers) belongs to a family of catkin-bearing trees, the Salicaceae. The basic chromosome number of Salix is 19, and most species are diploid $(2 \mathrm{x}=38)$, but ploidy levels up to dodecaploid $(12 x=228)$ have been reported [1]. Most willows can be easily propagated from hardwood cuttings, although some species are not good rooters e.g., S. caprea L. and S. scouleriana Barratt [2,3]. Salix flowers are predominantly insect-pollinated, but wind-pollination also occurs [4].

\footnotetext{
*Correspondence: perderea@tcd.ie

${ }^{1}$ Teagasc, Agriculture and Food Development Authority, Kinsealy Research Centre, Malahide Road, Dublin D17, Ireland

${ }^{2}$ Botany Building, School of Natural Sciences, Trinity College Dublin, Dublin D2, Ireland

Full list of author information is available at the end of the article
}

Microsatellite markers have been developed successfully for some species of willows. They have been characterized in Salix burjatica Nasarow [5], S. reinii Franch. \& L. Sav. [6], subarctic willows, S. lanata L., S. lapponum L. and S. herbacea L. [7], S. hukaoana Kimura [8], S. arbutifolia Pall. [9] and up to 31 different species of willows in Barker et al. (2003) [10]. A subset of markers from this later publication have been tested and applied in this paper. SSR markers were used as they are co-dominant and allow data comparison between different studies. A high level of polymorphism makes them suitable for inferring relatively recent population genetic events; they can also be used to genetically discriminate between individuals and populations [11].

Salix caprea is a cold-tolerant pioneer species native to Ireland which occurs in a broad range of habitats and 
is one of the few willow species able to grow in forest understories [12]. It is frequently found growing in hedgerows, by woodland margins or on rocky lake shores as it is more tolerant of dry situations than many other willows. It also colonises disturbed sites and waste ground [13]. It is sometimes used in breeding programmes for short rotation coppice cultivars [14]. Only one population genetic study has examined natural populations of S. caprea [15], which studied four PCR-RFLP markers and three chloroplast SSRs on 24 European populations. High levels of variation within populations were detected and no distinct phylogeographic structure was revealed among populations at the European scale. No studies have examined genetic variation in Irish S. caprea.

However, the molecular ecology of several other species of Salix has been studied throughout the world. Lian et al. (2003) [16] used nuclear and chloroplast microsatellites to examine population genetic structure and reproduction dynamics in $S$. reinii, a creeping shrub which is a pioneer colonist of volcanic substrates on Mount Fuji, Japan. Evidence of clonal growth and seedling recruitment were detected in this polyploid species.

A study has been conducted in the UK for conservation and restoration of S. lanata and S. lapponum [17]. They found distinct multi-locus genotypes for most individuals with five SSR markers, and were able to deduce that sexual reproduction is the predominant means of perpetuation and dispersal at the site of study. However, they also examined a more common subarctic willow $(S$. herbacea) and found evidence of clonal growth in individuals growing up to seven metres apart.

Another study in the USA focused on a native willow ( $S$. eriocephala Michx.) and a naturalized one (S. purpurea L.) to compare the genetic diversity and structure of their populations [18]. Their results revealed that some subpopulations of $S$. purpurea contained plants with identical multilocus genotypes (inferred to be clones), while clonal individuals were rare among $S$. eriocephala populations. They suggest that vegetative propagation in combination with sexual reproduction has contributed to the naturalization of $S$. purpurea in the USA and has resulted in higher levels of genetic differentiation among $S$. purpurea populations than among native $S$. eriocephala populations [18].

Population genetic structure was recently studied in the endangered Salix daphnoides Vill. in the Czech Republic [19]. 174 individuals from 14 populations were analysed using SSR and AFLP markers. High genotypic variability and heterozygosity were revealed with the SSR markers in the natural populations.

In order to investigate the genetic diversity, the extent of gene flow and the population genetic structure of natural Irish populations of $S$. caprea, we analysed nuclear and chloroplast microsatellite markers. A combination of statistics were applied including 1) traditional population- genetic methods that often require a priori population designation such as diversity statistics, allele frequencies across Ireland, unique genotypes, analysis of variance, and tests of isolation by distance, and 2) Bayesian algorithms that cluster individual samples into populations without $a$ priori population designation. Results were compared to those presented in previous studies on other woody species with a particular focus on Salicaceae.

The specific aims were to test existing chloroplast and nuclear SSR markers for their ability to detect and describe genetic diversity and differentiation of populations in S. caprea, describe nuclear and cpDNA allelic and haplotypic diversity in natural Irish populations of $S$. caprea, determine the level of geographic population genetic structure in natural Irish populations of S. caprea, and determine the extent of gene flow and sexual reproduction in this species.

\section{Methods}

\section{Sample collection}

Salix caprea was sampled in semi-natural woodlands, defined hereafter as "woodlands which resemble the natural woodland cover, dominated by native trees but altered by human activity. Stands originating from previous planting may be termed semi-natural if they are now regenerating naturally, as may stands which were formerly coppiced" [20]. Ireland is one of the least wooded countries in Europe with approximately $10 \%$ of land covered by forests. However 80,000 hectares or about one percent of Ireland's land area is native woodland with the rest being nonnative coniferous trees [21]. In order to find sites suitable for study, the herbarium specimens in Trinity College Dublin, Ireland and in the National Botanic Gardens, Dublin, Ireland were examined for site location information. The native woodland survey database [22] was also checked.

Samples of leaves of natural populations of Salix caprea were collected across Ireland during the summers of 2010 and 2011. 183 individuals from 21 sites in counties Cavan, Clare, Fermanagh, Galway, Laois, Leitrim, Longford, Mayo, Meath, Offaly, Roscommon, Tipperary, Waterford, Westmeath and Wicklow were sampled (Figure 1). Between 7 and 23 individuals were collected per site (Table 1). A few young green leaves were taken from each tree and stored in silica gel [23]. The distinction of Salix caprea from other willows is relatively clear. For correct identification in the field, Meikle, 1984 [13] and Webb et al., 1996 [24] were used.

\section{Amplification and genotyping}

DNA was extracted from dried leaf tissue with a DNeasy Plant Extraction kit (Qiagen, Valencia, CA, USA). The markers used included eight chloroplast and six nuclear SSR loci. The chloroplast SSR markers were produced 


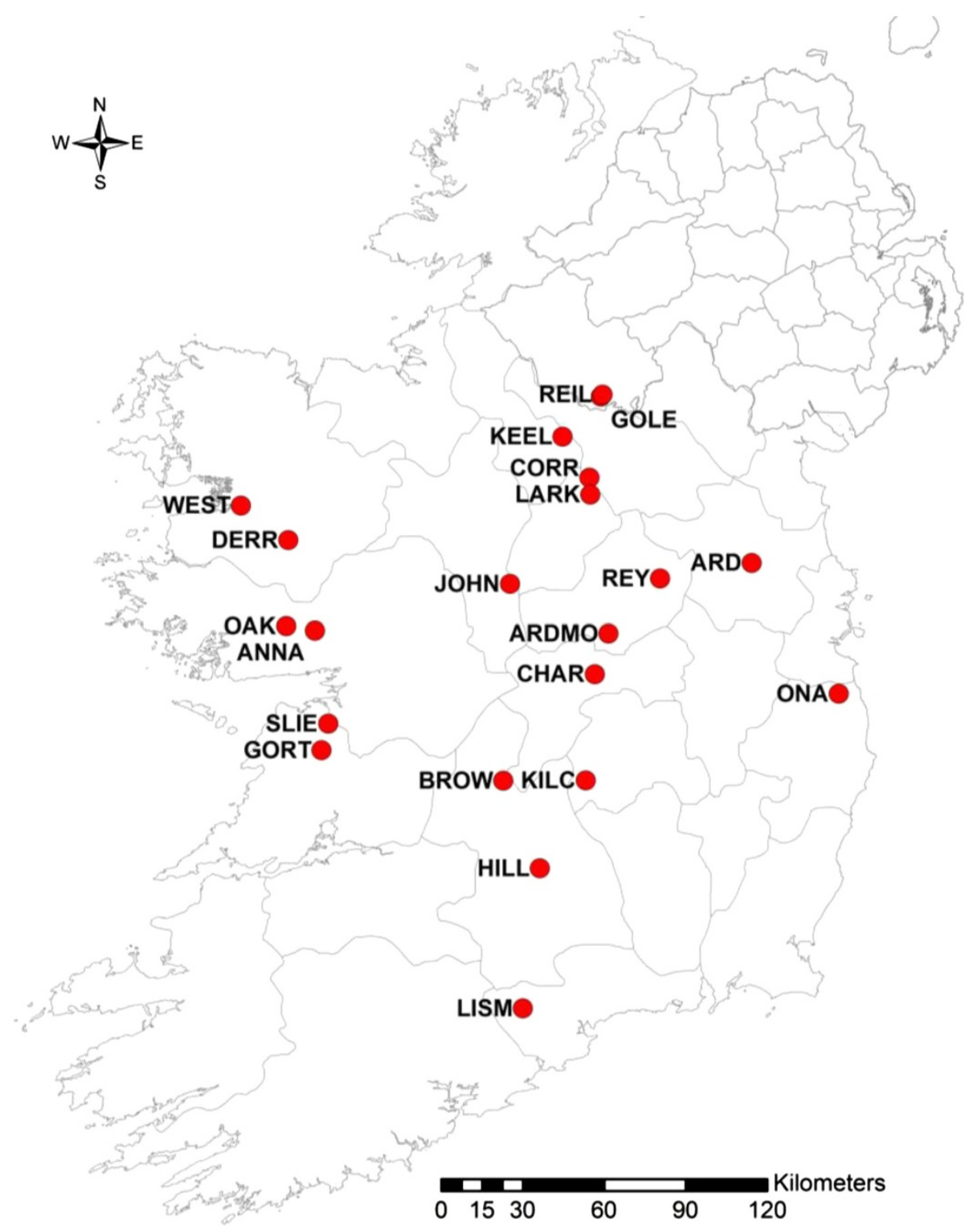

Figure 1 Sites for the natural populations of S. caprea.

using a set of primers designed for universal application for dicotyledonous angiosperms and were developed on tobacco (Nicotiana tabacum L.) [25]. CCMP2, 3, 4, 5, 6, 7, 8 and 10 were used. They are located mostly in intron and intergenic regions. The nuclear markers were designed specifically for Salix spp. from an enriched library of Salix burjatica [10]. SB24, 38, 85, 93, 194 and 199 were used. Loci were genotyped with automated capillary based electrophoresis and fluorescently labelled primers. Each forward primer of a pair was labelled on the $5^{\prime}$ end with a fluorescent dye (JOE ${ }^{\mathrm{mm}}$ TAMRA or 5-FAM ${ }^{\mathrm{mm}}$ ).

Prior to amplification by PCR, the quantity of DNA of each sample was checked using a NanoDrop 2000 spectrophotometer (Thermo Scientific). Amplification using the CCMP primers was as follows $(12.5 \mu \mathrm{L}$ total volume): 10 ng DNA, $1 \times$ colorless GoTaq ${ }^{\circ}$ Flexi Buffer, $0.2 \mathrm{mM}$ of each dNTP, $0.2 \mu \mathrm{M}$ of each primer, $1.5 \mathrm{mM}$ $\mathrm{MgCl}_{2}, 0.25$ units of GoTaq DNA Polymerase. Every primer was used at $0.2 \mu \mathrm{M}$ except forward and reverse primers of CCMP5 which were both used at $0.4 \mu \mathrm{M}$. PCR parameters included $95^{\circ} \mathrm{C}$ for 4 min, then 35 cycles at $95^{\circ} \mathrm{C}$ for $30 \mathrm{~s}, 50^{\circ} \mathrm{C}$ for $45 \mathrm{~s}$ and $72^{\circ} \mathrm{C}$ for $1 \mathrm{~min} 15 \mathrm{~s}$, following a final extension at $72^{\circ} \mathrm{C}$ for $8 \mathrm{~min}$. Amplification using the nuclear SB primers (12.5 $\mu \mathrm{L}$ total volume) used 10 ng DNA, 1× colorless GoTaq ${ }^{\circ}$ Flexi Buffer, $0.2 \mathrm{mM}$ of each dNTP, $0.32 \mu \mathrm{M}$ of each primer, $1.5 \mathrm{mM}$ $\mathrm{MgCl}_{2}, 0.25$ units of $\mathrm{GoTaq}^{\circ}$ DNA Polymerase. SB38 and SB85 forward and reverse primers were both at 


\begin{tabular}{lll} 
Table $\mathbf{1}$ List of the collection sites, code and number of \\
samples analysed \\
Location & Code & $\begin{array}{l}\text { Number of } \\
\text { samples }\end{array}$ \\
\hline Ardsallagh Co. Meath & ARD & 8 \\
Onagh Co. Wicklow & ONA & 8 \\
Reynella house Co. Westmeath & REY & 23 \\
Ardmorney Co. Westmeath & ARDMO & 8 \\
Larkfield Co. Longford & LARK & 8 \\
Corratober Co. Cavan & CORR & 8 \\
Keelrin Co. Leitrim & KEEL & 8 \\
Brownstown Co. Offaly & BROW & 8 \\
Kilcoke Co. Laois & KILC & 8 \\
Charleville Co. Offaly & CHAR & 8 \\
Annaghdown Co. Galway & ANNA & 8 \\
Slievecarron Co. Clare & SLIE & 8 \\
Gortlecka Co. Clare & GORT & 8 \\
St John's wood Co. Roscommon & JOHN & 8 \\
Oakfield Co. Galway & OAK & 8 \\
Westport Co. Mayo & WEST & 8 \\
Derrinrush Co. Mayo & DERR & 8 \\
Gole wood co. Fermanagh & GOLE & 7 \\
Reilly wood co. Fermanagh & REIL & 9 \\
Lismore co. Waterford & LISM & 8 \\
Killough hill co. Tipperary & HILL & 8 \\
\hline
\end{tabular}

$0.4 \mu \mathrm{M}$ whereas the others were at $0.32 \mu \mathrm{M}$. The PCR parameters were $94^{\circ} \mathrm{C}$ for $2 \mathrm{~min}$, then 35 cycles at $94^{\circ} \mathrm{C}$ for $40 \mathrm{~s}, 54^{\circ} \mathrm{C}$ for $1 \mathrm{~min}$ and $72^{\circ} \mathrm{C}$ for $2 \mathrm{~min}$, following a final extension at $72^{\circ} \mathrm{C}$ for $20 \mathrm{~min}$. The annealing temperature was different depending on the primers, it was $48^{\circ} \mathrm{C}$ for $\mathrm{SB} 38,50^{\circ} \mathrm{C}$ for $\mathrm{SB} 85,52^{\circ} \mathrm{C}$ for $\mathrm{SB} 194$ and $54^{\circ} \mathrm{C}$ for SB24, SB93 and SB199.

Between 1:5 and 1:80 dilutions were performed according to the brightness of the band after checking the quantity of DNA on an agarose gel. PCR products were multiplexed and $1 \mu \mathrm{L}$ of the diluted mix was added to $8.75 \mu \mathrm{L} \mathrm{Hi}$-Di formamide and $0.25 \mu \mathrm{L}$ of an internal lane size standard (Genescan ${ }^{\text {TM }}$ 400HD-ROX Standard; Applied Biosystems) and run on an ABI 3130xl Genetic Analyzer (Applied Biosystems), following the manufacturer's protocol. After genotyping, the fragments were sized using GeneMapper v4.1 (Applied Biosystems).

\section{Data analyses}

For both the chloroplast and nuclear markers, the frequency distribution of each marker was graphed in Microsoft Excel and mapped into ArcGIS 10.1 (ESRI) for each population. Diversity indicators were calculated in total, per population and per locus in GenAlEx 6.5 [26], POPGENE 1.31 [27] or Arlequin 3.1 [28]. Number of different alleles, number of effective alleles $\left(1 /\left(\Sigma p_{i}{ }^{2}\right)\right)$, Shannon's information index $\left(-1^{*} \Sigma\left(p_{i}^{*} \ln \left(p_{i}\right)\right)\right)$, gene diversity/expected heterozygosity [29] $\left(1-\Sigma p_{i}^{2}\right)$, (where $p_{i}$ is the frequency of the $\mathrm{i}^{\text {th }}$ allele and $\Sigma p_{i}^{2}$ is the sum of the squared allele frequencies), observed heterozygosity (number of heterozygotes/n) and Jost's estimate of differentiation [30,31] were calculated in GenAlEx [32].

POPGENE was used to calculate overall diversity in collections (total gene diversity $=H_{T}$ ), diversity within populations $\left(H_{S}\right)$, genetic differentiation $\left(G_{S T}=1-H_{S}\right)$ $H_{T}$ ), inbreeding coefficient within individuals in each subpopulation $\left(F_{I S}\right)$, inbreeding coefficient of an individual relative to the total population $\left(F_{I T}\right)$, inbreeding coefficient within subpopulations, relative to total (genetic differentiation among populations, $\left.F_{S T}=\left(H_{T}-H_{S}\right) / H_{T}\right)$. The values of $G_{S T}$ were taken to calculate the ratio of pollen mediated/seed mediated gene flow [33].

The average gene diversity over loci was calculated in Arlequin. Exact tests of Hardy-Weinberg (HW) equilibrium using a Markov chain were performed in Arlequin for the nuclear loci. Analyses of molecular variance (AMOVA) were carried out in Arlequin with two different analyses of distance, the number of different alleles $\left(F_{S T}\right)$ based on the infinite allele model and the sum of squared size difference $\left(R_{S T}\right)$ based on the stepwise mutation model. Gene flow was estimated from $F_{S T}$ obtained from the AMOVAs $\left(N m=\left(1-F_{S T}\right) / F_{S T}\right.$ for cpSSR data or $N m=0.25^{*}\left(1-F_{S T}\right) / F_{S T}$ for the nuclear SSR data) [34]. Unique multilocus genotypes per population and in total were inferred using GeneticStudio [35].

Isolation by distance (IBD) estimation was carried out using a Mantel test. Two types of test were made: 1) with all the individuals against the haploid genetic distances matrix (for the cpSSRs) or the codominant genotypic distances matrix (for the nuclear markers) obtained from GenAlEx, or 2) with the matrix of Slatkin linearized $F_{S T}$ for each population obtained from Arlequin [36]. Both tests were performed in GenAlEx with 9999 permutations.

Genetic structure was investigated using STRUCTURE v2.3.4. [37,38], which applies the Markov Chain Monte Carlo (MCMC) algorithm. This procedure clusters individuals into populations and estimates the proportion of membership in each population for each individual. An admixture model with correlated allele frequencies was used, the $K$ value was set from one to ten, and ten runs were performed for each value of $K$. The length of the burn-in period was set to 50,000, and the MCMC chains after burn-in were run for an additional 100,000 times. The optimal value of $K$ was determined by examination of the $\Delta K$ statistic [39] using Structure Harvester [40]. 


\section{Results}

\section{Overall frequencies of the alleles detected cPSSRs}

A maximum of one allele per locus per individual was detected. They were the predicted length suggesting there was no contamination and the target region was amplified. 31 alleles were discovered in total for the 8 cpSSRs. Microsatellites CCMP4 and CCMP7 were found to be monomorphic (respectively 113 and $133 \mathrm{bp}$ ) but the other microsatellites were variable, with mononucleotide repeats in every case ( 1 bp difference). Between 2 and 7 alleles per locus were found (Table 2). CCMP5 was the most variable, and CCMP10 was the least variable, with only 2 size variants (102 and $103 \mathrm{bp})$. No obvious geographical patterns were detected when the allele proportions at each microsatellite locus were mapped per population (data not shown).

\section{Nuclear SSRs}

All six nuclear markers were found to be polymorphic with between 3 and 16 alleles per locus $($ mean $=10)$ (Table 3). A total of 60 alleles were detected from the 6 markers. The repeats were di- or tri-nucleotide in every case. A maximum of two alleles per locus per individual was detected and this is consistent with the expectation that all plants were diploids. SB24 was the most variable with 16 alleles and SB85 was the least variable with only 3 alleles (Table 3). No obvious geographical patterns were detected when the allele proportions at each microsatellite locus were mapped per population (data not shown).

\section{Genetic diversity cPSSRs}

Indicators of genetic diversity are provided in Table 2 . The number of effective alleles $\left(N_{E}\right)$ ranged from 1.15 for CCMP10 to 3.66 for CCMP6. $H_{T}$ ranged from 0.13 for

Table 2 Diversity indicators for the different chloroplast SSR markers across all populations

\begin{tabular}{llllllllll}
\hline Locus & $\boldsymbol{N}$ & Pred & Size & $\boldsymbol{N}_{\boldsymbol{A}}$ & $\boldsymbol{N}_{\boldsymbol{E}}$ & $\boldsymbol{I}$ & $\boldsymbol{H}_{\boldsymbol{T}}$ & $\boldsymbol{H}_{\boldsymbol{S}}$ & $\boldsymbol{G}_{\boldsymbol{S} \boldsymbol{T}}$ \\
\hline CCMP2 & 170 & 189 & $210-215$ & 6 & 3.59 & 1.48 & 0.73 & 0.45 & 0.38 \\
CCMP3 & 183 & 112 & $102-104$ & 3 & 2.15 & 0.92 & 0.48 & 0.28 & 0.42 \\
CCMP5 & 180 & 121 & $101-107$ & 7 & 2.90 & 1.32 & 0.66 & 0.43 & 0.35 \\
CCMP6 & 179 & 103 & $108-116$ & 6 & 3.66 & 1.42 & 0.73 & 0.47 & 0.35 \\
CCMP8 & 183 & 77 & $69-73$ & 5 & 2.85 & 1.22 & 0.65 & 0.44 & 0.32 \\
CCMP10 & 181 & 103 & $102-103$ & 2 & 1.15 & 0.26 & 0.14 & 0.02 & 0.84 \\
CCMP4 & 155 & 126 & 113 & 1 & & & & & \\
CCMP7 & 179 & 133 & 133 & 1 & & & & & \\
Mean & 176 & & & 4.8 & 3.59 & 1.48 & 0.57 & 0.35 & 0.38 \\
SE & 1.98 & & & 0.8 & 2.15 & 0.92 & 0.05 & 0.03 &
\end{tabular}

$N=$ Sample Size, Pred = Predicted product size (bp) from Weising and Gardner [25] in tobacco, Size = Allele size range (bp), $N_{A}=$ No. of Obtained Alleles, $N_{E}=$ Effective No. of Alleles, $I=$ Shannon's Information Index, $H_{T}=$ Diversity in overall collections total gene diversity, $H_{S}=$ Diversity within populations, $G_{S T}=$ Genetic differentiation.
CCMP10 to 0.73 for CCMP6. $H_{S}$ was lower than the overall diversity for all markers, as not all the alleles were present in every population. $\mathrm{Nm}$ was equal to $2.29, \mathrm{Nm}>$ 1.0, which shows little differentiation among populations.

\section{Nuclear SSRs}

The number of effective nuclear alleles was lower than the total number of alleles, showing that few alleles contributed to the variation (Table 3). Average heterozygosities $\left(H_{E}\right)$ were variable across loci reflecting the different number and frequencies of the alleles found. For three loci, $H W$ tests were significant. It was especially visible for SB93 and SB199 where a small $H_{O}$ was observed, this was confirmed by both $F_{I S}$ and $F_{I T}$ where these indicators were found to be high, indicating a dearth of heterozygotes at these two loci. No excess of heterozygotes were detected even for the SB194 loci. Nm was equal to 2.76, $\mathrm{Nm}>1.0$ again, which indicates a constant gene flow among populations.

\section{Analysis per population}

A mean number of 2.2 alleles and 3.9 alleles were found per locus and per population for the chloroplast and nuclear SSRs respectively (Table 4). The average gene diversity over all samples was high and was similar for both types of markers (0.56), showing that two randomly chosen genes will carry different alleles roughly half of the time. For each population, the observed heterozygosities $\left(H_{O}\right)$ were less than the expected heterozygosities $\left(H_{E}\right)$ except for CORR and KILC where an excess of heterozygotes was observed.

\section{Genotypes}

79 haplotypes were discovered from the analysis of the cpSSRs when every allele from each individual were combined. Among them, 38 were unique and 41 were shared among two or more individuals (up to 10 individuals). In contrast, 165 unique multilocus genotypes were found for the nuclear markers (90.2\% of the individuals). Individuals WEST6, 7, 8 on the one hand and CORR2, $4,6,7,8$ on the other hand have the same genotypes. When the results are combined with the cpSSRs, CORR2 and 6, CORR4 and 7, and WEST7 and 8 have the same genotype, demonstrating that these individuals might be clonal.

\section{Genetic structure}

$G_{S T}$ was moderate for the cpSSR data (mean $G_{S T}=0.38$, Table 2). $F_{S T}$ calculated with the nuclear SSR data was between low and moderate depending on the locus (0.09-0.28, Table 3$)$ and the $G_{S T}$ was approximately twice as low (0.04-0.12) suggesting low differentiation. The ratio of pollen mediated/seed mediated gene flow was calculated according to Petit et al., 2005 [33]. The mean 
Table 3 Diversity indicators obtained from the nuclear SSR markers

\begin{tabular}{|c|c|c|c|c|c|c|c|c|c|c|c|c|c|c|}
\hline Locus & $N$ & Pred & Size & $N_{A}$ & $N_{E}$ & $I$ & $H_{O}$ & $H_{E}$ & $H W$ & $F_{I S}$ & $F_{I T}$ & $F_{S T}$ & $G_{S T}$ & $D_{\text {est }}$ \\
\hline SB24 & 362 & $109-245$ & 124-182 & 16 & 2.8 & 1.57 & 0.62 & 0.64 & NS & $-0.09^{N S}$ & 0.03 & $0.11^{* *}$ & $0.05^{* *}$ & $0.09 * *$ \\
\hline SB38 & 364 & 105-161 & $106-156$ & 15 & 9.0 & 2.34 & 0.86 & 0.89 & NS & $-0.09^{\mathrm{NS}}$ & 0.03 & $0.11^{* *}$ & $0.06^{* *}$ & $0.33^{* *}$ \\
\hline SB85 & 362 & $81-87$ & $79-85$ & 3 & 1.1 & 0.11 & 0.04 & 0.04 & NS & $-0.12^{N S}$ & -0.02 & $0.09^{*}$ & $0.04^{*}$ & $0.002^{*}$ \\
\hline SB93 & 336 & $159-185$ & $150-168$ & 7 & 2.1 & 0.92 & 0.07 & 0.53 & $S$ & $0.85^{\mathrm{NS}}$ & 0.88 & $0.23^{*}$ & $0.12^{*}$ & $0.13^{*}$ \\
\hline SB194 & 362 & $105-152$ & 108-130 & 11 & 5.9 & 1.95 & 0.75 & 0.83 & $S$ & $-0.04^{\mathrm{NS}}$ & 0.09 & $0.13^{* *}$ & $0.07^{* *}$ & $0.27^{* *}$ \\
\hline SB199 & 212 & $102-140$ & $98-126$ & 8 & 2.4 & 1.20 & 0.10 & 0.58 & $S$ & $0.71^{\mathrm{NS}}$ & 0.79 & $0.28^{*}$ & / & / \\
\hline Mean $^{1}$ & 333 & & & 10 & 3.9 & 1.35 & 0.41 & 0.58 & & $0.08^{\mathrm{NS}}$ & 0.30 & $0.16^{* *}$ & $0.07^{* *}$ & $0.10^{* *}$ \\
\hline SE & 24.6 & & & 2 & 1.2 & 0.32 & 0.15 & 0.12 & & & & & & \\
\hline
\end{tabular}

$N=$ Sample Size, Pred = Predicted product size (bp) from Barker [10], Size = Allele size range (bp), $N_{A}=$ No. of Obtained Alleles, $N_{E}=$ No. of Effective Alleles, $I=$ Shannon's Information Index, $H_{O}=$ Observed Heterozygosity, $H_{E}=$ Expected Heterozygosity, $H W=$ exact test of Hardy-Weinberg equilibrium with a significance at $p=0.01, F_{I S}=$ Inbreeding coefficient within individuals in each subpopulation, $F_{\Pi T}=$ Inbreeding coefficient of an individual relative to the total population, $F_{S T}=$ Genetic differentiation among populations, $G_{S T}=$ Analog of $F_{S T}, D_{\text {est }}=$ Jost's estimate of differentiation. ${ }^{1}$ Mean over loci rather than the arithmetic average, ${ }^{\mathrm{NS}}$ non significant, ${ }^{*} \mathrm{P}<0.05$;

**P $<0.001$ Probability values are based on 999 permutations.

values of $G_{S T}$ from Table 2 and Table 3 were taken to calculate the ratio, which was found to be equal to 6.8 .

A third measure of differentiation was calculated in GenAlEx, Jost's $D\left(D_{\text {est }}\right)$ [30]. Jost suggests that when using highly polymorphic markers to examine differentiation among populations, $G_{S T}$ or its analogues should not be used because when diversity is high this measure will approach zero (no differentiation). These data support this, as SB85 was the least variable and SB38 was the most variable even though their $G_{S T}$ is similar (0.04 against 0.06$)$.

Table 4 Diversity indicators per population obtained from the chloroplast and nuclear SSR markers

\begin{tabular}{|c|c|c|c|c|c|c|c|c|c|c|}
\hline \multirow[b]{2}{*}{ Sampling site } & \multirow[b]{2}{*}{$N$} & \multicolumn{3}{|c|}{ cpSSRs } & \multicolumn{6}{|c|}{ Nuclear SSRs } \\
\hline & & $\overline{U H}$ & $A$ & $H$ & $\overline{U G}$ & $A$ & $H$ & $H_{E}$ & $H_{O}$ & $P$ \\
\hline$\overline{\text { ANNA }}$ & 8 & 63 & 2.2 & 0.41 & 100 & 4.5 & 0.59 & 0.56 & 0.51 & 83.3 \\
\hline ARD & 8 & 88 & 2.3 & 0.43 & 100 & 3.8 & 0.49 & 0.48 & 0.39 & 83.3 \\
\hline ARDMO & 8 & 63 & 2.7 & 0.53 & 100 & 4.2 & 0.60 & 0.52 & 0.35 & 83.3 \\
\hline BROW & 8 & 75 & 2.3 & 0.46 & 100 & 3.3 & 0.48 & 0.46 & 0.46 & 66.7 \\
\hline CHAR & 8 & 75 & 2.3 & 0.42 & 100 & 4.2 & 0.52 & 0.48 & 0.39 & 83.3 \\
\hline CORR & 8 & 63 & 2.2 & 0.32 & 37.5 & 2.8 & 0.37 & 0.35 & 0.48 & 66.7 \\
\hline DERR & 8 & 75 & 2.5 & 0.42 & 100 & 5.3 & 0.58 & 0.58 & 0.46 & 100 \\
\hline GOLE & 7 & 71 & 2.0 & 0.31 & 100 & 4.2 & 0.62 & 0.54 & 0.51 & 100 \\
\hline GORT & 8 & 75 & 2.3 & 0.54 & 100 & 3.8 & 0.47 & 0.45 & 0.32 & 83.3 \\
\hline HILL & 8 & 75 & 1.8 & 0.34 & 100 & 3.3 & 0.52 & 0.48 & 0.40 & 83.3 \\
\hline $\mathrm{JOHN}$ & 8 & 63 & 2.0 & 0.27 & 100 & 4.0 & 0.53 & 0.51 & 0.40 & 83.3 \\
\hline KEEL & 8 & 88 & 3.0 & 0.58 & 100 & 3.7 & 0.56 & 0.53 & 0.42 & 83.3 \\
\hline KILC & 8 & 88 & 2.5 & 0.45 & 100 & 4.0 & 0.50 & 0.41 & 0.44 & 83.3 \\
\hline LARK & 8 & 75 & 2.2 & 0.40 & 100 & 4.5 & 0.56 & 0.51 & 0.39 & 100 \\
\hline LISM & 8 & 50 & 1.5 & 0.24 & 100 & 4.0 & 0.56 & 0.57 & 0.43 & 100 \\
\hline OAK & 8 & 50 & 2.2 & 0.27 & 100 & 3.8 & 0.55 & 0.51 & 0.40 & 83.3 \\
\hline ONA & 8 & 88 & 2.8 & 0.49 & 100 & 4.7 & 0.61 & 0.56 & 0.44 & 83.3 \\
\hline REIL & 9 & 67 & 1.8 & 0.29 & 100 & 3.8 & 0.58 & 0.53 & 0.41 & 83.3 \\
\hline REY & 23 & 43 & 2.5 & 0.47 & 100 & 4.5 & 0.51 & 0.50 & 0.37 & 83.3 \\
\hline SLIE & 8 & 50 & 1.7 & 0.21 & 100 & 2.8 & 0.42 & 0.39 & 0.38 & 66.7 \\
\hline WEST & 8 & 50 & 1.8 & 0.34 & 62.5 & 2.7 & 0.45 & 0.45 & 0.33 & 83.3 \\
\hline Average over populations & & 68 & 2.2 & 0.39 & 95.6 & 3.9 & 0.53 & 0.49 & 0.41 & 84.1 \\
\hline Average* & 8.7 & 48.1 & 4.8 & 0.56 & 90.2 & 10.2 & 0.56 & 0.59 & 0.41 & 100 \\
\hline
\end{tabular}

$N=$ Number of samples per site, $U H=$ unique haplotypes (\%), $A=$ Mean number of alleles, $H=$ Average gene diversity over loci, $U G=$ unique multilocus genotypes (\%), $H_{E}=$ Expected Heterozygosity, $H_{O}=$ Observed Heterozygosity, $P=$ Polymorphic loci (\%), *Average over all samples, individuals analysed independently from their geographic origin. 
$D_{\text {est }}$ was very low for SB85 (0.002) and considerably higher for SB38 and SB194 (0.33 and 0.27). It was moderate for SB24 and SB93.

\section{AMOVA}

Two locus by locus AMOVA analyses per marker type were carried out in Arlequin using two distance measures: $F_{S T}$ and $R_{S T}$ (Table 5). From the cpSSR data, both analyses showed that the variation was mostly within populations (70\% for the $F_{S T}$ based AMOVA and $63 \%$ for the $R_{S T}$ based AMOVA), the rest of the variation being among populations (Table $5 \mathrm{~A}$ and B). Genetic differentiation among populations was found to be moderate as the $F_{S T}$ associated with both AMOVAs were significant at 0.304 and 0.371. The two AMOVAs computed with the nuclear data did not produce the same results. The first AMOVA based on $F_{S T}$ shows that most of the variation was within individuals $(68.9 \%$, Table $5 \mathrm{C}$ ) while for the AMOVA based on the $R_{S T}$ analysis, it shows that most of the variation was among individuals within populations $(62.4 \%$, Table $5 \mathrm{D}$ ). A negative variance component was found in Table $5 \mathrm{D}$, resulting in a negative $R_{S T}$ which sometimes occurs because what is calculated is a covariance. It shows that there is an absence of genetic structure. It can also have a biological meaning. For instance, in dioecious organisms like $S$. caprea, genes from different populations can be more related to each other than genes from the same population.

\section{IBD}

For the cpSSR data, the first Mantel test among all individuals showed a slight pattern of isolation by distance, although the slope was nearly equal to zero $(y=0.0016 \mathrm{x}+$ $\left.3.2762 ; R^{2}=0.0051, p<0.0001\right)$. However, the $2^{\text {nd }}$ test with Slatkin linearized $F_{S T}$ showed no IBD $\left(\mathrm{y}=5 \cdot 10^{-5} \mathrm{x}+\right.$ 0.4624; $\mathrm{R}^{2}=5.10^{-5}, p=0.426$ ). For the nuclear SSR data, similar results to the cpSSR analysis were obtained (data not shown). The first test among all individuals was significant $\left(\mathrm{y}=0.0036 \mathrm{x}+8.961 ; \mathrm{R}^{2}=0.0046, p=0.003\right)$ but the Mantel test based on population $F_{S T}$ showed no significance $\left(\mathrm{y}=-0.6 .10^{-04} \mathrm{x}+0.1108 ; \mathrm{R}^{2}=0.0038, p=0.266\right)$.

\section{Bayesian clustering}

The clustering implemented within STRUCTURE software supported an optimal value of $K$ to be $K=2$ for both types of markers. The two clusters were mapped for each population (cpSSR: Figure 2, nuclear SSR: Figure 3). A slight geographic pattern of structure was detected especially in the cPSSR analysis. For instance, individuals mostly associated with cluster 2 were more common in the western populations and individuals mostly associated with cluster 1 in the eastern populations. Such structuring is consistent with the AMOVA results for cPSSRs. WEST had a different pattern from the other western populations. ANNA, SLIE and GORT had very similar patterns, and so too did LISM, LARK and CORR. For the nuclear SSR analysis, the OAK, ANNA, KEEL, REIL, GOLE, JOHN, ARDMO and ONA populations had a similar pattern while cluster 1 was more common in the other populations.

\section{Discussion}

Genetic diversity and gene flow

Every SSR marker primer pair successfully amplified the target DNA in S. caprea. The cpDNA markers were

Table 5 Analyses of molecular variance for cpSSR and nuclear SSR data

\begin{tabular}{|c|c|c|c|c|c|}
\hline & AMOVA (cpSSRs) & Sum of squares & Variance components & Explained variance \% & $F_{S T}$ \\
\hline \multirow[t]{3}{*}{ A) Based on $F_{S T}$} & Among sites & 114 & 0.53 & 30.4 & $0.304^{* * *}$ \\
\hline & Within sites & 192 & 1.21 & 69.6 & \\
\hline & Total & 306 & 1.74 & 100 & \\
\hline \multirow[t]{4}{*}{ B) Based on $R_{S T}$} & Among sites & 493 & 2.46 & 37.1 & $0.371^{* * *}$ \\
\hline & Within sites & 654 & 4.16 & 62.9 & \\
\hline & Total & 1147 & 6.62 & 100 & \\
\hline & AMOVA (nuclear SSRs) & Sum of squares & Variance components & Percentage variation & $F_{S T}$ \\
\hline \multirow[t]{4}{*}{ C) Based on $F_{S T}$} & Among sites & 85 & 0.15 & 8.3 & $0.083^{* * *}$ \\
\hline & Among individuals within sites & 284 & 0.40 & 22.8 & \\
\hline & Within individuals & 217 & 1.22 & 68.9 & \\
\hline & Total & 586 & 1.77 & 100 & \\
\hline \multirow[t]{4}{*}{ D) Based on $R_{S T}$} & Among sites & 10229 & -5.59 & -1.8 & $-0.018^{\mathrm{NS}}$ \\
\hline & Among individuals within sites & 51350 & 193.97 & 62.4 & \\
\hline & Within individuals & 20574 & 122.25 & 39.4 & \\
\hline & Total & 82153 & 310.63 & 100 & \\
\hline
\end{tabular}

***p-value over 1000 permutations $<0.0001 ;{ }^{\mathrm{NS}}$ non-significant $p$-value $>0.05$. 


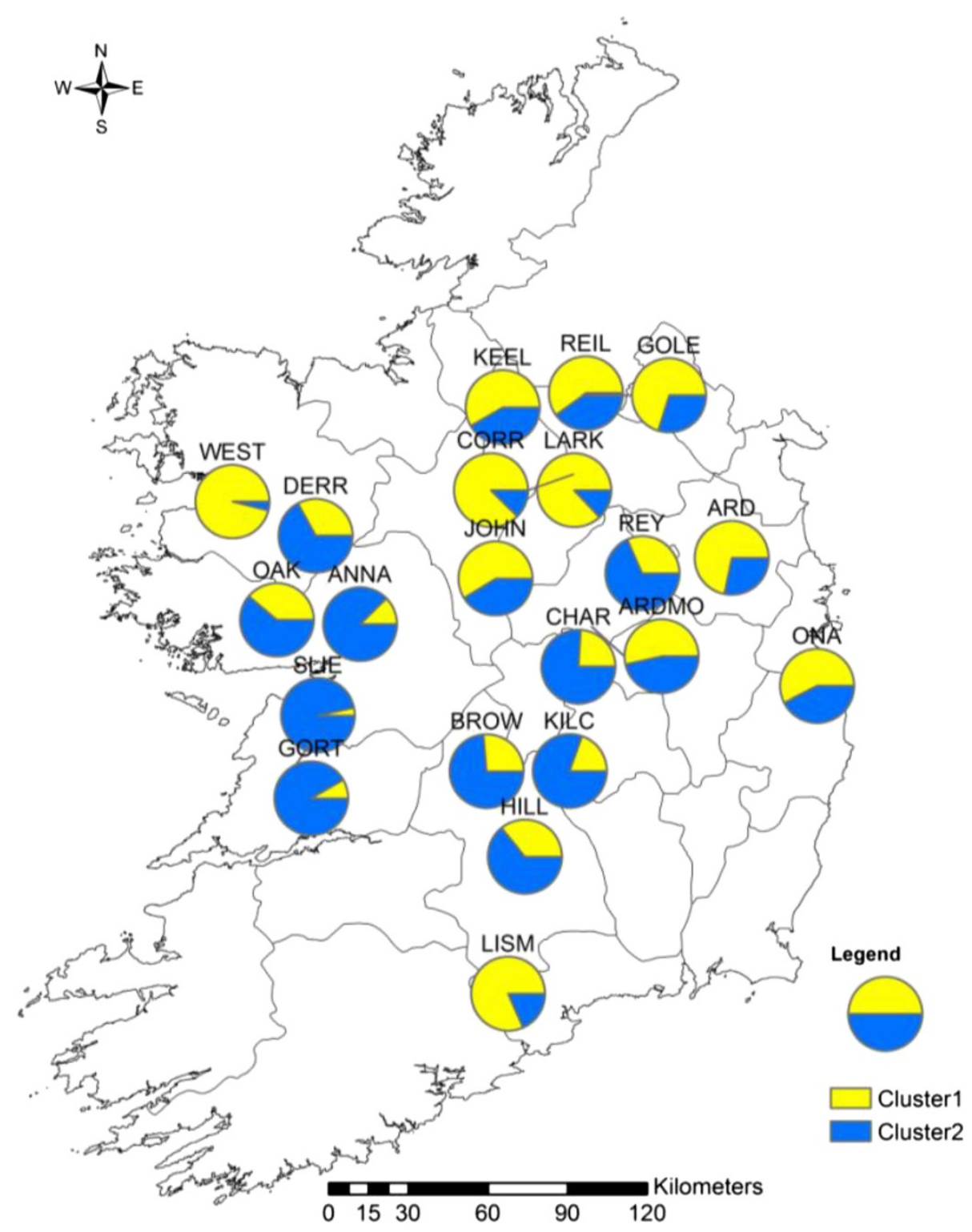

Figure 2 Cluster identity of individuals within S. caprea populations obtained from STRUCTURE for the chloroplast SSR analysis. Between 7 and 23 individuals per population were mapped.

designed as universal markers in dicotyledonous angiosperms on tobacco [25] and this study has demonstrated their utility in Salix caprea. The same is true of the nuclear microsatellite markers applied in this study. They detected a high level of diversity and were useful for studies of population genetic structure. The nuclear SSR markers were designed for Salix burjatica [10] and have been shown to work well here on S. caprea. The allele size ranges found in this study are within the ranges found in Barker et al., 2003 [10] except for SB85, SB93 and SB199 where the size range was slightly different (Table 3 ).

Some of the CCMP alleles can be compared with those found for another microsatellite study on 24 populations of S. caprea sampled across Europe [15]. In both studies, CCMP7 was found to be monomorphic (135 bp against $133 \mathrm{bp}$, Table 2). CCMP10 had limited variation: 3 alleles were found (107, 109, 110 bp) in Palmé et al., 2003 [15] against 2 for our study (102 and $103 \mathrm{bp}$ ). Five alleles were found for CCMP2 in Palmé et al. [15] (206, 208$211 \mathrm{bp})$. Six alleles of nearly similar sizes were found in our study (210-215 bp). The fragment analysis method used was not the same, manual acrylamide gels were run in Palmé et al. [15] which could explain the differences.

All S. caprea individuals studied displayed a high level of cpDNA and nuclear DNA SSR allelic variation and a considerable number of genotypes were found within 


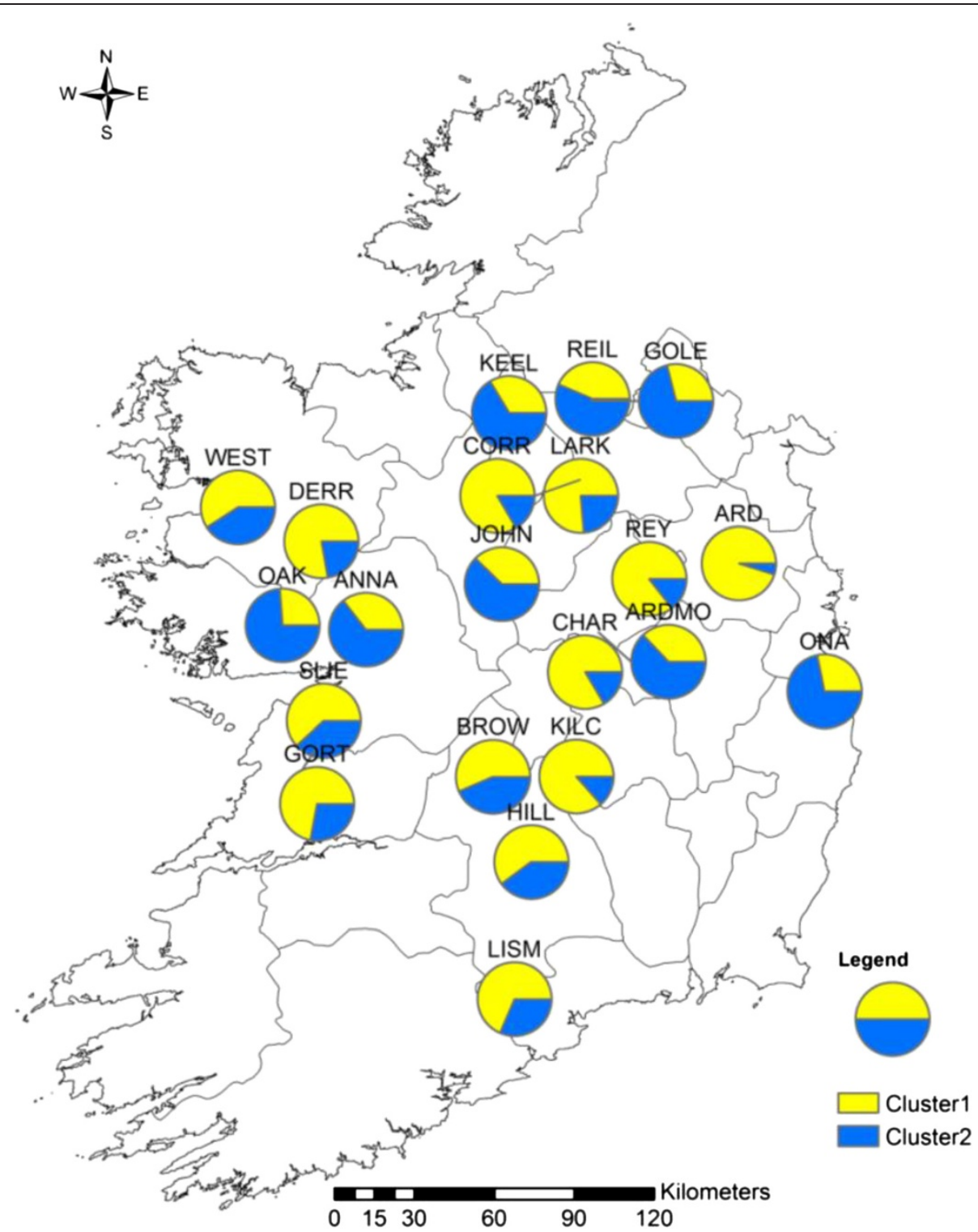

Figure 3 Cluster identity of individuals within S. caprea populations obtained from STRUCTURE for the nuclear SSR analysis. Between 7 and 23 individuals per population were mapped.

and among populations. This high allelic variation could be explained by the fact that $S$. caprea is an outcrossing species producing numerous very small seeds, bearing a tuft of long hairs encouraging wind dispersal [41]. Propagules could also have been moved deliberately or accidentally by, for example, grazers, birds or humans. We have detected numerous genotypes within and between S. caprea populations which would suggest that seed dispersal is high over Ireland. It is consistent with a study on natural populations of $S$. viminalis in the Czech Republic [42] that found that $92 \%$ of the individuals had unique multilocus genotypes with 38 nuclear microsatellites analysed. A few individuals were found to have both the same chloroplast and nuclear genotypes (CORR2 and CORR6, CORR4 and CORR7, WEST7 and WEST8). Microsatellite markers and especially the nuclear ones in this study are highly polymorphic, so it can be inferred that these individuals could be clonal. However, as $S$. caprea seems to be a species that is recalcitrant against natural vegetative regeneration [3], it is possible that these individuals are introgressed hybrids of $S$. caprea, probably with $S$. cinerea ssp. oleifolia (S. xreichardtii Kern.), as this hybrid is frequent in Ireland [13] and it was noted during morphological examination in the Corratober (CORR) population when the samples were collected.

All populations showed relatively high values of observed heterozygosity $\left(H_{O}=0.41\right.$ for the nuclear SSRs) and gene diversity $(H=0.39$ for the cpSSRs and $H=0.53$ 
for the nuclear SSRs) which are comparable to other Salicaceae like Populus tremuloides, S. purpurea, S. viminalis or $S$. daphnoides $[18,19,42,43]$. Overall genetic variability for the samples studied, represented by Shannon's information index values, was particularly high with an average of 1.48 for the cpSSRs and 1.35 for the nuclear SSRs. The high value of Shannon's index represents the effectiveness of microsatellite loci to reveal the variation.

$N m$, estimated gene flow from $F_{S T}$ was 2.29 for the cpSSRs and 2.76 for the nuclear SSRs on average. In both cases $N m$ was superior to 1.0 , which shows a constant gene flow between populations (i.e. at least one migrant per generation); therefore populations are expected to remain genetically stable over time [44]. $\mathrm{Nm}$ decreases with increasing $F_{S T}$ because greater differentiation between populations corresponds to lower levels of gene flow [11]. For an outcrossing, dioecious species like $S$. caprea which is partly wind pollinated, gene flow is expected to be high between and within populations [45]. From our data, gene flow is expected to occur by pollen and a bit less through seeds. In fact, the ratio of pollen mediated/seed mediated gene flow was found to be approximately equal to 7 . It indicates that gene flow via pollen is approximately 7 times higher than via seeds. It is not as high as the median of the ratio found in Petit et al., 2005 [33], which was based on 93 plant species and equal to 17. Seed dispersal in $S$. caprea appears to account for a large (roughly 13\%) component of total gene flow.

\section{Population structuring}

Genetic differentiation $\left(G_{S T}\right)$ of populations was pronounced for the cpSSRs ( 0.38 on average) but low for the nuclear microsatellites ( 0.07 on average). It is not completely unexpected as cpDNA is generally maternally inherited in angiosperms [46,47] and has therefore a smaller effective population size than nuclear DNA. Hence, genetic drift acts more intensively upon chloroplast than nuclear DNA, although pollen mediated and seed mediated gene flows were found to be nearly equal. Maternal inheritance also means that cpDNA is only dispersed through seeds. It implies that $G_{S T}$ among populations is generally more pronounced for cpDNA than nuclear DNA. $G_{S T}$ was found to be much lower for populations of $S$. caprea sampled across Europe for chloroplast DNA [15]. They have found a $G_{S T}$ of 0.090 for PCR-RFLP markers and a $G_{S T}$ of -0.017 for cpSSRs.

From the nuclear SSR analysis, low to moderate genetic differentiation between populations was discovered depending on the method used $\left(F_{S T}=0.08-0.16 ; D_{e s t}=\right.$ $\left.0.10 ; G_{S T}=0.07\right)$. These values are higher than those estimated for natural populations of $S$. viminalis in the Czech Republic $\left(F_{S T}\right.$ of 0.05 ) based on 38 nuclear SSRs [42] but comparable to Bulgarian populations of Fraxinus excelsior trees $\left(F_{S T}\right.$ of 0.09) based on six nuclear SSRs [48].
AMOVA results for the cpSSR study showed that most of the variation was within populations but among population variation was moderate (30 to $37 \%$ ). For the nuclear SSRs study, however, the among population genetic variation estimations were substantially lower and differed depending on the method used. Most of the variation was estimated to occur within individuals for the $F_{S T}$-AMOVA but mostly among individuals within sampling sites for the $R_{S T}$-AMOVA. These results are in accordance with other outcrossing woody species [49] and with other Salicaceae like Populus nigra or S. viminalis [42,50]. In another study on 16 populations of $P$. nigra across Europe, $90 \%$ of the genetic variation was found within populations for the microsatellite data used [51]. The results of these studies are based on $F_{S T}$ only.

The tests for isolation by distance gave similar results for both the cPSSR and nuclear markers. A slight IBD was identified for the tests among all individuals on pairwise distances but no IBD was detected for the tests with the linearized $F_{S T}$ among the sampled sites. This is in accordance with a study on $S$. viminalis in the Czech Republic [42]. The IBD tests were also in accordance with the Bayesian analysis of the possible structuring of the populations. This analysis identified two putative clusters for both analyses, but little obvious geographical pattern was detected for the clusters. From the cpSSR study, a slight North-East versus West structuring could be detected. It was especially visible for the two populations in the Burren, GORT and SLIE. These populations are nearly only clustered in cluster 2 which could be indicative of a limited gene flow through seeds with the other populations. Human activities in the Burren are perhaps lower than the other regions, possibly reducing the amount of artificial gene flow. The limited substructuring detected may also be influenced by ecogeographical factors such as rainfall, temperature and soil type. This structuring is not shown in the nuclear analysis, probably indicating a stronger pollen-mediated gene flow between populations. Our study, despite detecting some among population differentiation with the cPSSR markers, is largely consistent with a study on populations of $S$. caprea across Europe where an absence of geographical structure was found from the analysis of three cpSSRs and four PCR-RFLPs [15].

Sexual reproduction is inferred to be high for $S$. caprea within the sampling area and this is expected as $S$. caprea is recalcitrant to natural vegetative regeneration except for a few genotypes [3]. Our data, in which a high number of multilocus genotypes were unique to a single individual (90\% for the nuclear markers) and $G_{S T} / F_{S T} /$ $D_{\text {est }}$ values were low especially for the nuclear SSRs, are consistent with outbreeding and indicate that there are no significant barriers for sexual reproduction and gene flow within Ireland over large geographic distances. 
Both pollen-mediated and seed-mediated gene flow are high, some of the populations being $230 \mathrm{~km}$ apart from each other. Such a finding could simply be due to human intervention through seed trade, extensive planting or accidental transportation of both seeds and pollen. The absence of population structure could indicate the existence of one largely continuous population throughout Ireland. A parentage study has not been undertaken in our work but the results could also be consistent with long distance pollination. Parentage analyses were undertaken in Populus trichocarpa [52]. In a study site of $>300 \mathrm{~km}^{2}$ (radius $10 \mathrm{~km}$ ) in western Oregon, the mean pollination distance was $7.6 \mathrm{~km}$, with many recorded matings over $10 \mathrm{~km}$ [52]. They could not estimate the maximum distance pollen could travel in $P$. trichocarpa, as the maximum within stand pollination distance simply reflects the maximum potential distances between trees within the study site, which was verified for other studies [53].

\section{Conclusion}

This paper used chloroplast and nuclear microsatellites to examine the genetic diversity, the geographic population genetic structure and the extent of gene flow in natural populations of $S$. caprea across Ireland. New markers were tested and shown to be suitable for genetic characterization of S. caprea. High levels of allelic and genetic diversity were found with these markers, with within population variation accounting for the majority of the variation, and a high number of unique genotypes detected. Population structure and differentiation analyses, as well as IBD tests confirmed low levels of geographical structuring of variation but moderate differentiation was detected with the cpSSRs. However, gene flow through seeds and pollen was shown to be large. These results are of value for breeders wishing to exploit natural populations and foresters having to choose planting material. Further analysis should analyse the variation of Irish populations in relation to those found in Europe.

\section{Competing interests}

The authors declare that they have no competing interests.

\section{Authors' contributions}

AP sampled the specimens, performed the experiments, analysed the data and wrote the paper. CK sampled the specimens and contributed to experimental design, analysis and writing of the manuscript. TH contributed to sampling, experimental design, analysis and writing of the manuscript. GD contributed to sampling, experimental design and writing of the manuscript. All authors read and approved the final manuscript.

\section{Acknowledgements}

We thank Dr. Daniel Kelly, Trinity College Dublin, Ireland for sampling help and Dr. Philippe Cubry for technical support. We also thank the public and private owners for access to the sampling sites. The research is supported by a Walsh Fellowship PhD studentship Grant from Teagasc, The Irish

Agriculture and Food Development Authority.

\section{Author details}

'Teagasc, Agriculture and Food Development Authority, Kinsealy Research Centre, Malahide Road, Dublin D17, Ireland. 'Botany Building, School of Natural Sciences, Trinity College Dublin, Dublin D2, Ireland. ${ }^{3}$ Trinity Centre for Biodiversity Research, Trinity College Dublin, Dublin D2, Ireland. ${ }^{4}$ DBN Plant Molecular Laboratory, National Botanic Gardens, Glasnevin, Dublin D9, Ireland.

Received: 15 May 2014 Accepted: 17 July 2014

Published: 7 August 2014

\section{References}

1. Suda Y, Argus GW: Chromosome numbers of some North American Salix. Brittonia 1968, 20:191-197.

2. Dickmann DI, Kuzovkina J: Poplars and willows of the world, with emphasis on silviculturally important species. In Rome, Italy: FAO Forest Management Division Working Paper IPC/9-2. 2008:1-125.

3. Liesebach M, Naujoks G: Approaches on vegetative propagation of difficult-to-root Salix caprea. Plant Cell Tiss Org Cult 2004, 79:239-247.

4. Argus GW: An experimental study of hybridization and pollination in Salix (willow). Can J Bot 1974, 52:1613-1619.

5. Edwards KJ, Barker JHA, Daly A, Jones C, Karp A: Microsatellite libraries enriched for several microsatellite sequences in plants. Biotechniques 1996, 20:758-760.

6. Lian C, Nara K, Nakaya H, Zhou Z, Wu B, Miyashita N, Hogetsu T: Development of microsatellite markers in polyploid Salix reinii. Mol Ecol Notes 2001, 1:160-161.

7. Stamati K, Blackie S, Brown JWS, Russell J: A set of polymorphic SSR loci for subarctic willow (Salix lanata, S. lapponum and S. herbacea). Mol Ecol Notes 2003, 3:280-282.

8. Kikuchi S, Suzuki W, Ban N, Kanazashi A, Yoshimaru H: Characterization of eight polymorphic microsatellites in endangered willow Salix hukaoana. Mol Ecol Notes 2005, 5:869-870.

9. Hoshikawa T, Kikuchi S, Nagamitsu T, Tomaru N: Eighteen microsatellite loci in Salix arbutifolia (Salicaceae) and cross-species amplification in Salix and Populus species. Mol Ecol Resour 2009, 9:1202-1205.

10. Barker JHA, Pahlich A, Trybush S, Edwards KJ, Karp A: Microsatellite markers for diverse Salix species. Mol Ecol Notes 2003, 3:4-6.

11. Freeland JR, Petersen SD, Kirk H: Molecular Ecology. 2nd edition. Chichester, UK: Wiley-Blackwell; 2011.

12. Preston $C D$, Pearman D, Dines TD: Willows. In New atlas of the British \& Irish flora: an atlas of the vascular plants of Britain, Ireland, the Isle of Man and the Channel Islands, Illustrated, reprint edition. Edited by Preston CD, Pearman D, Dines TD, Isles BSB. Oxford: Oxford University Press; 2002:236-249.

13. Meikle RD: Willows and Poplars of Great Britain and Ireland, Illustrated, reprint edition. London, UK: Botanical Society of the British Isles; 1984.

14. Wickham J, Rice B, Finnan J, McConnon R: A review of past and current research on short rotation coppice in Ireland and abroad. Dublin: COFORD; 2010.

15. Palmé AE, Semerikov V, Lascoux M: Absence of geographical structure of chloroplast DNA variation in sallow, Salix caprea L. Heredity 2003, 91:465-474.

16. Lian CL, Oishi R, Miyashita N, Nara K, Nakaya H, Wu BY, Zhou ZH, Hogetsu T: Genetic structure and reproduction dynamics of Salix reinii during primary succession on Mount Fuji, as revealed by nuclear and chloroplast microsatellite analysis. Mol Ecol 2003, 12:609-618.

17. Stamati K, Hollingsworth PM, Russell J: Patterns of clonal diversity in three species of sub-arctic willow (Salix lanata, Salix lapponum and Salix herbacea). Plant Syst Evol 2007, 269:75-88.

18. Lin J, Gibbs JP, Smart LB: Population genetic structure of native versus naturalized sympatric shrub willows (Salix; Salicaceae). Am J Bot 2009, 96:771-785.

19. Sochor M, Vasut RJ, Bartova E, Majesky L, Mracek J: Can gene flow among populations counteract the habitat loss of extremely fragile biotopes? An example from the population genetic structure in Salix daphnoides. Tree Genet Genomes 2013, 9:1193-1205.

20. Forest Service: Native Woodland Scheme. Johnstown Castle Estate, co. Wexford, Ireland: Forest Service, Department of the Marine and Natural Resources; 2001.

21. Service F: National Forest Inventory Republic of Ireland Results. Dublin: Government Publications; 2007. 
22. Perrin P, Martin J, Barron S, O'neill F, Mcnutt K, Delaney A: National survey of native woodlands -volume 1 main report. Report to the National Parks \& Wildlife Service; 2008. http://www.npws.ie/media/npws/publications/ reports/media,6688,en.pdf.

23. Chase MW, Hills HH: Silica gel: an ideal material for field preservation of leaf samples for DNA studies. Taxon 1991, 40:215-220

24. Webb DA, Parnell J, Doogue D: Salicaceae. In An Irish Flora. 7th edition. Dundalk, Ireland: Dundalgan Press; 1996:21-25.

25. Weising K, Gardner RC: A set of conserved PCR primers for the analysis of simple sequence repeat polymorphisms in chloroplast genomes of dicotyledonous angiosperms. Genome 1999, 42:9-19.

26. Peakall R, Smouse PE: GenAlEx 6.5: genetic analysis in Excel. Population genetic software for teaching and research-an update. Bioinformatics 2012, 28:2537-2539.

27. Yeh FC, Yang R-C, Boyle TB, Ye Z, Mao JX: POPGENE, the user-friendly shareware for population genetic analysis. In Molecular Biology and Biotechnology Centre. Canada: University of Alberta; 1997:10.

28. Excoffier L, Laval G, Schneider S: Arlequin (version 3.0): an integrated software package for population genetics data analysis. Evol Bioinformatics 2005, 1:47-50.

29. Nei M: Analysis of gene diversity in subdivided populations. Proc Nat Acad Sci 1973, 70:3321-3323.

30. Jost L: $G_{S T}$ and its relatives do not measure differentiation. $\mathrm{Mol}$ Ecol 2008, 17:4015-4026.

31. Meirmans PG, Hedrick PW: Assessing population structure: FST and related measures. Mol Ecol Resour 2011, 11:5-18

32. Nei M: Molecular Evolutionary Genetics. New York: Columbia University Press; 1987.

33. Petit RJ, Duminil J, Fineschi S, Hampe A, Salvini D, Vendramin GG: Comparative organization of chloroplast, mitochondrial and nuclear diversity in plant populations. Mol Ecol 2005, 14:689-701.

34. Hamilton MB, Miller JR: Comparing relative rates of pollen and seed gene flow in the island model using nuclear and organelle measures of population structure. Genetics 2002, 162:1897-1909.

35. Dyer RJ: GeneticStudio: a suite of programs for spatial analysis of genetic-marker data. Mol Ecol Resour 2009, 9:110-113.

36. Slatkin M: A measure of population subdivision based on microsatellite allele frequencies. Genetics 1995, 139:457-462.

37. Falush D, Stephens M, Pritchard JK: Inference of population structure using multilocus genotype data: linked loci and correlated allele frequencies. Genetics 2003, 164:1567-1587.

38. Pritchard JK, Stephens M, Donnelly P: Inference of population structure using multilocus genotype data. Genetics 2000, 155:945-959.

39. Evanno G, Regnaut S, Goudet J: Detecting the number of clusters of individuals using the software STRUCTURE: a simulation study. Mol ECOl 2005, 14:2611-2620.

40. Earl DA, von Holdt BM: STRUCTURE HARVESTER: a website and program for visualizing STRUCTURE output and implementing the Evanno method. Conserv Genet Resour 2012, 4:359-361.

41. Newsholme C: Willows: the genus Salix. Illustratedth edition. London, UK: BT Batsford Ltd; 1992.

42. Trybush SO, Jahodova S, Cizkova L, Karp A, Hanley SJ: High levels of genetic diversity in Salix viminalis of the Czech Republic as revealed by microsatellite markers. Bioenergy Res 2012, 5:969-977.

43. De Woody J, Rickman TH, Jones BE, Hipkins VD: Allozyme and microsatellite data reveal small clone size and high genetic diversity in aspen in the southern Cascade Mountains. For Ecol Manage 2009, 258:687-696.

44. Lowe A, Harris S, Ashton P: Ecological Genetics: Design, Analysis, and Application. Malden, USA: Oxford: Blackwell; 2004

45. Loveless MD, Hamrick $\mathrm{J}$ : Ecological determinants of genetic structure in plant populations. Annu Rev Ecol Systematics 1984, 15:65-95.

46. Dumolin S, Demesure B, Petit RJ: Inheritance of chloroplast and mitochondrial genomes in pedunculate oak investigated with an efficient PCR method. Theor App/ Genet 1995, 91:1253-1256.

47. Rajora OP, Dancik BP: Chloroplast DNA inheritance in Populus. Theor Appl Genet 1992, 84:280-285.

48. Heuertz M, Hausman JF, Tsvetkov I, Frascaria-Lacoste N, Vekemans X: Assessment of genetic structure within and among Bulgarian populations of the common ash (Fraxinus excelsior L.). Mol Ecol 2001, 10:1615-1623.

49. Hamrick $J$, Godt MJW: Effects of life history traits on genetic diversity in plant species. Philos Transact A Math Phys Eng Sci 1996, 351:1291-1298.
50. Imbert E, Lefevre F: Dispersal and gene flow of Populus nigra (Salicaceae) along a dynamic river system. J Ecol 2003, 91:447-456.

51. Smulders MJM, Cottrell JE, Lefevre F, van der Schoot J, Arens P, Vosman B, Tabbener HE, Grassi F, Fossati T, Castiglione S, Krystufek V, Fluch S, Burg K, Vornam B, Pohl A, Gebhardt K, Alba N, Agúndez D, Maestro C, Notivol E, Volosyanchuk R, Pospíšková M, Bordács S, Bovenschen J, van Dam BC, Koelewijn HP, Halfmaerten D, Ivens B, van Slycken J, Vanden Broeck A, et al: Structure of the genetic diversity in black poplar (Populus nigra L.) populations across European river systems: consequences for conservation and restoration. For Ecol Manage 2008, 255:1388-1399.

52. Slavov GT, Leonardi S, Burczyk J, Adams WT, Strauss SH, Difazio SP. Extensive pollen flow in two ecologically contrasting populations of Populus trichocarpa. Mol Ecol 2009, 18:357-373.

53. Ashley MV: Plant parentage, pollination, and dispersal: how DNA microsatellites have altered the landscape. Crit Rev Plant Sci 2010, 29:148-161.

\section{doi:10.1186/s12870-014-0202-x}

Cite this article as: Perdereau et al:: High levels of gene flow and genetic diversity in Irish populations of Salix caprea L. inferred from chloroplast and nuclear SSR markers. BMC Plant Biology 2014 14:202.

\section{Submit your next manuscript to BioMed Central and take full advantage of:}

- Convenient online submission

- Thorough peer review

- No space constraints or color figure charges

- Immediate publication on acceptance

- Inclusion in PubMed, CAS, Scopus and Google Scholar

- Research which is freely available for redistribution

Submit your manuscript at www.biomedcentral.com/submit
C) Biomed Central 